\title{
THE RELATIONSHIPS BETWEEN SCHOOL INSPECTIONS, SCHOOL CHARACTERISTICS AND SCHOOL IMPROVEMENT
}

\author{
by M.C.M. EHren and A.J. VISSCHER, University of Twente, \\ The Netherlands
}

\begin{abstract}
The effects of school inspections on school improvement have been investigated only to a limited degree. The investigation reported on in this article is meant to expand our knowledge base regarding the impact of school inspections on school improvement. The theoretical framework for this research is partly based on the policy theory behind the Dutch Educational School Supervision Act (the latter includes assumptions about how school inspections lead to school improvement). Interviews and a survey with school inspectors gave insight into how school inspectors implement the Supervision Act and how they assess schools, and stimulate schools to improve. The results of ten case studies showed that all schools started to improve after a school visit. The innovation capacity of the school and the school environment do not seem to contribute to school improvement after school inspections. No effects were found on school-improvement processes of the number of insufficient scores that schools received from inspectors, the extent of feedback and suggestions for improvement, and the number of agreements. The provision of feedback about weaknesses, the assessment of these weak points as unsatisfactory, and the agreements between an inspector and the school regarding improvement activities do appear to make a difference in promoting school improvement.
\end{abstract}

Keywords: school inspections, school improvements, school effectiveness

\section{INTRODUCTION}

The relationship between school inspection and school improvement is a relevant one as most Inspectorates of Education aim to contribute to some kind of improvement within schools. For example, the Dutch Supervision Act of 2002 states that 'through inspection the government guarantees that schools will deliver a satisfactory level of 
educational quality for all citizens', and that 'through inspection, the government stimulates schools to develop their own quality assurance systems, which will lead to improvement in the quality of education'. The British Office for Standards in Education (Ofsted) states on its website that "we aim to improve current provision and outcomes, to raise aspirations and to contribute to a longer term vision for achieving ambitious standards'.

The ways in which Inspectorates try to realise the goal of improvement vary. In an overview of the characteristics of Inspectorates of Education in Europe, Standaert (2000) described how all schools in England, Scotland, Flanders, the Czech Republic and Northern Ireland receive systematic, full inspections. In Portugal, Denmark and France the range of school inspections varies from full inspections of both schools and individual teachers, to inspections of specific subjects only. Differences also exist between countries with regard to the level of monitoring by inspectors for compliance with legal regulations, and/or the degree to which they encourage schools to improve by giving advice and recommendations to school leaders and teachers. Sometimes Inspectorates act as in-service trainers for teachers.

The Dutch supervision framework for assessing school performance includes aspects of the teaching-learning process, the school results, and the school organisational conditions (such as the school's educational policy). These topics are also included in the inspection frameworks applied in other European countries, although the specific focus may differ. In England, for example, school supervision focuses on the quality of education, educational standards, the management of financial resources, and the spiritual, moral, social and cultural development of pupils (www.ofsted.gov.uk). The Flemish supervision framework includes aspects of the school context (e.g. material means), input (school resources), the process (educational policy and the teaching-learning process) and output (e.g. student performance).

School visits which include observation of lessons are a common feature of inspection in Europe (Standaert, 2000). Other elements of school visits in most countries include: interviews with school leaders, teachers and sometimes with parents and pupils; questionnaires to be completed by school staff in preparation for the school visits; and the study of school documents (for example about pupil care).

Differences between countries predominantly concern the followup after school inspection, and the legal consequences of a school either failing to comply with regulations, or performing at an unsatisfactory level according to the school inspectorate. In the 
Netherlands, when a school is deemed to be underperforming significantly, the Inspectorate has a legal basis on which to take action only if the school does not comply with the legal regulations.

Owing to the Freedom of Education (parents may, if they meet specific requirements, found government-funded schools based on their religious or pedagogical opinions), central government and the Inspectorate have a reserved role, and Dutch schools have much freedom. Schools are sometimes invited to draw up an action plan to address the weaknesses outlined in the inspection report. Action plans are obligatory in England, and inspectors in other countries carry out follow-up school visits in cases of school underperformance more often than in the Netherlands. In a limited number of countries, such as England and the Netherlands, school inspection reports are published on the Internet.

The focus of this study was on school inspections in Dutch primary schools where information is collected to assess school quality. In cases of underperformance, a follow-up school visit and the request for an action plan written by the school are not obligatory but optional.

Whether school inspections contribute to school improvement has been studied scientifically only incidentally. The only country with any research tradition in this area is Great Britain. Although some British studies have shown that school inspections may generate changes in the behaviour of school leaders and teachers, and that inspections may even lead to some form of school improvement, the findings of the extant studies are not consistent.

Wilcox and Gray (1996) reported on case studies in which head teachers and senior staff tended to see the recommendations as support for their existing ideas and desires for change; inspections apparently legitimised their plans. Gray (cited in Visscher and Coe, 2002, p. 2) and Kogan and Maden (1999) described how school inspections contributed to how schools seemed to promote the commitment of teachers, the implementation of rules of conduct for students, strategies for raising examination results, and changes in management styles and structures. Ouston et al. (1997) concluded that school inspections led to school improvement only if schools had received a negative or only slightly positive assessment from the inspectorate. Matthews and Sammons (2004) found evidence of improved school quality, especially among the weakest schools, based on inspection evidence and on the performance of schools' students in national tests and examinations. Although the studies presented thus far do suggest a relationship between school inspection and school improvement, research by Earley (1998), Gray and 
Wilcox (1995) and Kogan and Maden (1999) suggest that inspections generally bring about little improvement in the quality of teaching and learning within schools. Shaw et al. (2003) and Rosenthal (2004) even found a slight decline in student achievement levels in the years of inspection visits!

Ferguson et al. (2000) in their well-known evaluation of Ofsted's school inspections in line with this state that English school inspections mainly serve accountability and are no effective catalyst for school improvement. The authors hold a plea for school selfinspections in tandem with Ofsted inspections.

In conclusion, there is a dearth of scientific research into the effects of school inspection, and about the conditions which may facilitate school improvement. As far as the latter issue is concerned, Ouston et al. (1997) stated that the impact of school inspections is strongest if the inspection report has indicated a poorly functioning school. According to Chapman (2001) the requirement for schools to develop a plan to improve their weaknesses also contributes to school improvement. Teachers seem to regard oral and written feedback from school inspectors as an important stimulus for school improvement (Brimblecombe et al., 1996; Chapman, 2001). Feedback given in a private setting and fitting with a school's culture seems to have a particularly positive impact (Standaerd, 2000). The nature of the relationship between school inspector and school probably also plays a role in the acceptance or rejection of the feedback. Ouston et al. (1997) and Leeuw (2002) suggested that school inspectors who have a good relationship with the school would probably have most impact as the schools would be more open about their strengths and weaknesses, and would be more receptive to improvement suggestions. Fidler et al. (1998) also point to other features of school inspections which may influence school improvement such as the inspector's attitude, the perceived inspection quality, the manner in which the inspector provides feedback, the extent to which the inspection report is experienced as relevant and correct and the congruence between the inspector's recommendations and the school culture.

School characteristics may also explain differences in school improvement as a result of inspections. The culture of a school and its innovation capacity may, for example, contribute to positive changes in the school. Genuine school improvement, according to Standaerd (2000), requires that the school staff is willing to change. A school with a high innovation capacity is one which is capable of implementing change. This type of school is, according to Reezigt (2001), experienced at reflecting on its functioning and at changing 
and improving. Participation in decision-making, cooperation between teachers and a shared vision are also important factors.

Consistent with the aforementioned, this investigation intends to expand the knowledge base regarding the impact of school inspections on the functioning of schools by addressing the questions, 'What effects, if any, do school inspections have on school improvement, and to what extent do the characteristics of schools and (the characteristics of) school inspections contribute to these effects?'.

\section{Theoretical Framework}

The theoretical framework for this research is based partly on the policy theory behind the Dutch Educational School Supervision Act. This legislation was implemented in 2002 and the policy theory behind it was deduced by Ehren et al. (2005). The Supervision Act includes implicit assumptions about how school inspections lead to school improvement. School improvement, for the purposes of this study, is defined as actions which schools take in order to improve the achievement levels of their students.

The assumptions underlying the Supervision Act were elicited by Ehren et al. (2005) through the analysis of documents regarding the Supervision Act, and by interviewing those policy makers who contributed significantly to the content of this Act. The analysis led to a focus on three core aspects of school inspection which, in the Supervision Act, are assumed to promote school improvement: quality assessment, proportionate inspection and the publication of inspection findings.

How each of these three 'improvement promoters' is assumed in the law to contribute to school improvement, and what the research literature tells us about their impact, are explained below. Finally, the results of a survey of and interviews with school inspectors regarding their methods of implementation of the Supervision Act are described. The survey of inspectors was offered to all (93) Dutch inspectors of primary education on the Internet. Almost 60 per cent of inspectors (54 respondents) completed the questionnaire. The inspectors were selected to match the population on all relevant features, except that some regional offices were slightly overrepresented (e.g. Utrecht), while others (e.g. Groningen) were under-represented.

The first items on the questionnaire were questions about the perceived intentions of the Dutch Educational Supervision Act and inspectors' own intentions. In addition, several questions were asked about the behavioural characteristics involved in determining and 
promoting good education including assessing schools, giving feedback, making agreements and monitoring schools. The interviews and the survey were designed to gain insight into how school inspectors assess schools and how they stimulate schools to improve (e.g., the relationships inspectors have with schools, the way in which they give feedback and make agreements with schools). The descriptions of each of the three core aspects of the Supervision Act led to the hypotheses tested in this study.

\section{Quality Assessment}

Dutch school inspectors should assess school quality using the school supervision framework which is intended to provide insight into the value added by schools to students' school entrance levels and insight into the prerequisites for adding value. The Educational Supervision Act assumes that school inspectors provide feedback to schools on their strengths and weaknesses including suggestions on how to improve. In line with the Act, schools assessed by inspectors as 'weak schools' should be visited more intensively and more frequently than other schools, and inspectors should draw up written agreements with these schools about the improvements required. Schools may also be requested to describe how they will attempt to implement the school improvement action plan and these plans should be monitored thereafter by the school inspector. In the Supervision Act it is expected that this approach will enable schools to learn about their strengths and weaknesses and, if underperforming, to improve. Improvement is defined, in the Act, in terms of added value: the extent to which schools add more value to their students' school entry performance levels (and how that compares with the average value added by schools with similar student populations, in terms of school entry level, or students' socio-economic status).

The literature review showed that some British school inspection studies support the assumption that the combination of the provision of feedback, and the formulation by schools of improvement plans does lead to school improvement. Chapman (2001) found, for example, that the obligation to develop a school improvement plan following an inspection visit contributed to school improvement. In the research of Brimblecombe et al. (1996), and Chapman (2001) it was found that teachers value the feedback from school inspectors as an important impulse for school improvement activities, especially if given in a setting of trust instead of in a context of punishment. The findings of Ouston, Fidler and Earley (1997) demonstrate that school inspections promote greater school improvement if the 
school report details the respect(s) in which the school has performed poorly. In summary, the literature review supports the assumption in the Supervision Act that school quality assessment does lead to school improvement. However, the literature on school improvement reveals that quality assessment alone is not a sufficient prerequisite. Geijsel (2001) and Fullan (1991) concluded, for example, that not every school is willing to change, or capable of successful change without assistance. Standaert (2000) notes that the impact of inspections depends, amongst other things, on the school staff's attitude to change. Some schools are not only more inclined than others to use the recommendations from inspectors, but are also more capable of implementing the changes required. Two preconditions for the implementation of inspection feedback, according to Matthews and Sammons (2004), are leadership which can generate and execute a strategy for the implementation of inspection outcomes, including action planning and the identification of the required resources. A school is capable of change, according to Geijsel et al. (1996), if it is able to implement innovations initiated either by the government, or by the school itself and, if necessary, to match the innovation initiatives at both levels. Geijsel et al. (1996) stressed the importance of the concept of the school as a learning organisation, cooperation between teachers, and transformative leadership. Schools with a high innovation capacity are expected to be more capable of successful change. In these schools improvement is a continuous process, and they are probably more willing to accept the feedback from the school inspector and to use it for their own improvement. Schools with lower innovation capacity require support from external bodies/actors such as external advisors to implement successful change or improvement. The two preconditions for school improvement - innovation capacity and support from the school environment - have been included in the theoretical framework of this investigation.

The survey of and interviews with school inspectors showed that they vary in the ways in which they evaluate schools and stimulate improvement. Some inspectors assess schools more thoroughly than others, some also explain more than others about the methods they use, and some focus more on improvement suggestions; some especially put effort into agreements and improvement plans, while yet others invest more in monitoring the school following the inspection visit. These differences were interpreted as variations in inspection style and labelled as 'directive' or 'reserved' (see Ehren et $a l$., in press). With the directive approach, an inspector clearly points out the strengths and weaknesses of the school, the probable 
causes of its level of functioning, and potential improvements. The inspector may put pressure on the school to improve by drawing up written agreements regarding how to change (for example, in the school report), and by requesting the school to elaborate on these agreements in an improvement plan. It should be added that variations in inspection styles officially are not permitted in any countries; the inspection is meant to be uniform to allow for comparisons.

With the reserved inspection style, the school is provided only with information on the strong and weak aspects of its functioning, with little elaboration. The distinction between the two school inspection styles is therefore particularly related to the degree to which a school inspector tries to encourage a school to improve: at the extremes a reserved school inspector does not try to force a school to improve, whereas a directive school inspector uses all possible means to do so.

\section{Proportionate Inspection}

Proportionate inspection is the second component of the Educational Supervision Act expected to lead to school improvement. With proportionate school inspection the results of schools' quality assurance and self-evaluation activities are used by the inspectorate to formulate judgments about schools' qualities. This method is expected to encourage schools to develop adequate quality assurance measures and as a result to identify and correct their own weaknesses.

Proportionate inspection is also expected to promote school improvement through an efficient allocation of inspection capacity. The intensity with which weak schools are inspected should increase, whereas the inspection capacity stays the same (which implies that schools functioning relatively well are inspected less intensively). It is assumed that a weak school will improve if it is subjected to more frequent and intense inspections. For this to happen, however, the inspectorate would need to be capable of identifying weak schools by assessing the soundness of schools' quality assurance procedures, and the actual results of their self-evaluations, that is, the assessments schools make of their own educational quality based on the indicators included in the inspectorate's supervision framework.

Although the literature review pointed out that proportionate school inspection is a new phenomenon which has not yet been thoroughly investigated, some preliminary findings (Janssens, 2005) suggest that proportionate inspection may lead to negative side effects as schools do not feel obliged to report on their risks and weaknesses in documents they write for school inspections. Matthews 
and Sammons (2004) reported, for example, that some British schools use two types of self-evaluations - one for their own purpose and one for the inspectorate. The self-evaluation reports presented to the school inspector present a more positive picture of the school.

The results of the survey and the interviews with the school inspectors showed that due to the limited implementation period of the Supervision Act, proportional inspection had not been implemented fully in Dutch primary schools at the time of our research. As a result the impact of proportionate inspection could not be studied.

\section{Publication of Inspection Findings}

The publication of inspection findings is intended to enable parents to contribute to school improvement by their choice of school for their children. It is expected that if schools are aware that the best schools are the most popular, they will be motivated to improve. It is also expected that parents would use the public inspection findings in order to request their school to improve, where necessary.

The literature review disclosed some limitations with respect to the assumption that the publication of inspection findings would lead to school improvement. Research (Dronkers and Veenstra, 2001; Educational Council, 2001; Karsten and Visscher, 2001) shows that parents are often interested in aspects of schools other than those reflected in the inspection results and school performance indicators. Parents have been found to be primarily concerned about the school atmosphere, its pedagogical climate, the instruction methods used, school safety, the clarity of school regulations, the reputation of the school and the decisions concerning the promotion of pupils. Parents do not generally become involved in matters relating to educational quality, nor are their school choices based on information on educational quality. If parents do suggest possible improvements in the functioning of the school, these usually relate to preconditions for the teaching-learning process, such as school timetables.

With regard to the publication of inspection findings, the survey of primary school inspectors found that half of the school inspectors did not think of parents as the main audience for school reports, and only four per cent of the school inspectors thought that parents should have a role in school improvement.

As the literature review indicated that the publication of inspection findings probably does not contribute to school improvement, and school inspectors do not seem to take any measures to ensure that 
parents use the report, no hypotheses were formulated regarding the publication of school findings.

The following hypotheses were formulated based on a combination of the policy theory on which the Supervision Act is based, the literature review and the data collected (interviews and survey) from school inspectors.

1. School inspections would lead to higher levels of school improvement if inspections included more of those elements which are expected to enhance the intended inspection effects, such as: low scores on important indicators of the quality of school functioning, a combination of various types of feedback to schools, improvement suggestions to the school, agreements about required improvements, and the monitoring of school improvement plans by the inspectorate.

2. The higher the innovation capacity of schools, the more probable it would be that school improvement initiatives would be undertaken.

3. The higher the number of actors/bodies within the school environment which support school improvement, the higher the number of school improvement initiatives that would be observed.

4. The higher the number of school improvement initiatives undertaken in schools, the more likely the intended effect of school improvement in terms of higher levels of value added by the school.

The following hypotheses refer to how school improvement processes were expected to occur after an inspection visit.

5. The more insight the school has into its strengths and weaknesses and the more these have been communicated with the school during the inspectorate visit, the greater would be the acceptance of that feedback.

6. The more the school accepts the feedback from the inspectorate, the more the school would initiate school improvement activities.

The assumptions in the Supervision Act which have been translated into the six hypotheses (i.e., assumptions about quality assessment) were further explored by means of case studies.

\section{Method}

The six hypotheses were tested in an exploratory way by selecting case studies from ten Dutch primary schools between 2002 and 2005. The following issues were investigated in depth: What improvement 
activities do schools initiate and implement following inspection? What relationships exist between schools implementing improvement initiatives, the characteristics of schools, and the styles of school inspectors?

\section{Selection of Cases}

To test the hypotheses, cases were selected by combining inspectors with different inspection styles with schools with different innovation capacities. The Inspection Style Questionnaire was completed by 45 inspectors (Ehren et al., in press) and the information gleaned was used to assist in the selection of inspectors for this study. The questionnaire results were combined with information from two assessments by inspection supervisors on the inspection styles of their subordinates. Inspectors thus received three scores regarding their inspection style, and those inspectors who were categorised at least twice as 'directive', or 'reserved' were included in the research. One inspector with an 'average inspection' style (neither very directive nor very reserved) was also included in this study.

All 567 Dutch primary schools inspected by the inspectors involved in the research were contacted and asked to fill out a validated questionnaire (Geijsel, 2003) which was designed to measure various aspects of schools' innovation capacities. Of the 190 schools which completed the questionnaire, the ten per cent of schools with the highest innovation capacity and the ten per cent of schools with the lowest innovation capacity were selected. Schools and inspectors were thereafter matched in such a way that the hypotheses could be tested. Table 1 presents the characteristics of the cases studied in the research.

\section{TABLE 1: Characteristics of the case study inspector-school combinations}

\begin{tabular}{lll}
\hline Case Number & Inspection Style & School Innovation Capacity \\
\hline 1 & Directive & Low \\
2 & Directive & Low \\
3 & Directive & Average \\
4 & Directive & High \\
5 & Directive & High \\
6 & Directive & High \\
7 & Average & Low \\
8 & Reserved & Average \\
9 & Reserved & High \\
10 & Reserved & High \\
\hline
\end{tabular}


The selection of case studies was based on the level of school innovation capacity and the inspection style of the inspectors, as these two variables could be measured prior to the inspection visit to the school. The other variables in the hypotheses could be measured only during or after the school visit.

\section{Data Collection Instruments}

Data were gathered in the schools by means of interviews, a questionnaire, observations during the inspection visits, and by analysis of documents such as school inspection reports and school documents. In addition to this, some information was collected in advance of the inspection visits about some of the variables included in the hypotheses: schools' improvement plans, the features of inspection visits relating to the inspector's style, the innovation capacity of the school, and the support for school improvement activities from bodies/actors within the school environment. These variables were also studied during the school visit and the reaction of the school to the inspection visit was also observed, while after the visit data collection was focused on the school's responses to the inspection visit. Table 2 shows what information was obtained and by what means.

To measure the intended effects of school inspections, school improvement activities initiated by schools were monitored until six months after the inspection visit: the feedback which had been provided to the school during the inspection visit or afterwards in the form of the school report was shown then once more to the school leader. They were asked what elements of the feedback they remembered, whether they agreed with the feedback, and whether the feedback had led to new improvement plans, or to adjustments in already existing improvement activities.

The hypotheses were tested by comparing the effects on those cases which to a large extent include the features of school inspections and of schools as formulated in the hypotheses, with the effects on those cases in which these features are minimally extant.

\section{Characteristics of the Data Collected}

Testing the hypotheses was restricted by the fact that our data collection was limited to a two-year period which meant that added value effects of school inspections in terms of changes in student performance could not be investigated. Therefore, the intermediate effects of school inspections were investigated, i.e. schools' responses to inspection visits in terms of the improvement activities undertaken 
Method of data collection

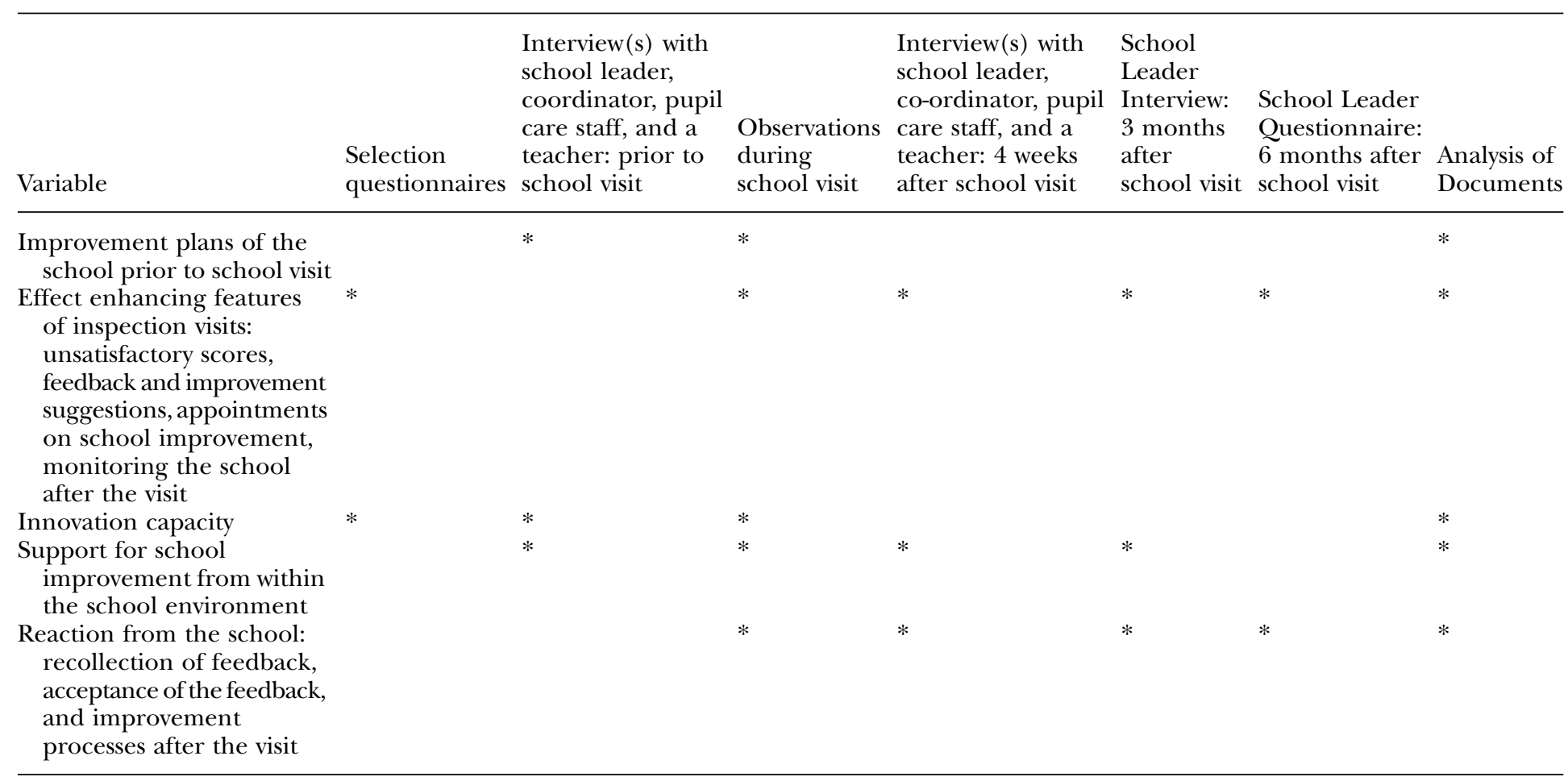

Note: *refers to the methods used to measure the indicated variable. 
by schools after the school inspection visit. It is believed that these intermediate effects precede added value effects.

As feedback from school inspectors is often related to the improvement processes the school had started prior to the visit, careful study was required to investigate which effect(s) could be attributed to the inspection visit. Therefore, a response from the school counted as an effect of the inspection visit only where feedback from the school inspector led to new improvement plans, or to changes in existing improvement plans.

Only minor differences in inspection style were found between the inspectors participating in this study. Contrary to expectation, all school inspectors gave feedback to schools, not only those with a directive inspection style.

Almost all school inspectors refrained from making agreements with schools, and from monitoring the school after visiting them. A possible explanation for this may be that school inspectors are influenced by the specific situation in the school, such as the educational quality, and/or the innovation capacity of the school. This may cause them to change the inspection style they usually employ. If they observe, for example, that the educational quality of a school is very low, they might decide to give feedback on how to improve the educational quality, where they would not usually provide feedback.

Differences in school innovation capacities existed as expected. The degree of support from the environment in carrying through improvements after the visit also varied between schools.

\section{Results}

Each of the cases received a score from the researchers on each core variable. Table 3 presents each variable and its scoring system. Table 4 presents an overview of the results achieved for the features of schools and school inspections which are expected to promote improvement processes. Table 5 shows the schools' responses to the inspection visits, including school improvement initiatives.

The ten cases were compared in order to test the hypotheses and to discover the combinations of school features and school inspection characteristics which contributed to school improvement initiatives.

\section{Features of School Inspections}

The higher the number of unsatisfactory inspection scores, the higher the scores were expected to be on the following variables: the 
TABLE 3: Overview of core variables and their potential scores

Variable Computation of the scores

Innovation capacity The average score of all answers provided by schools on the innovation capacity scale items. Scale ranged from 1 (low innovation capacity) to 4 (high innovation capacity).

Support from A percentage representing that part of the feedback and school environment improvement suggestions for which the school receives support from the school environment Scale ranged from $0 \%$ to $100 \%$.

Assessment of The number of performance indicators assessed as school functioning unsatisfactory in the inspection report. Scale ranged from 0 (none) to 37 (all indicators were assessed as unsatisfactory).

Feedback and improvement suggestions The number of school weaknesses and improvement suggestions the school inspector communicates during the visit and in the written report. Numbers can vary from 0 (the inspector does not give any feedback during the visit, or in the report) to a very high number (when the inspector continuously provides feedback during the visit).

Agreements and improvement plan The number of improvement topics which have been laid down in written agreements between the inspector and the school, and which will have to be elaborated in an improvement plan. Numbers can vary from 0 (no agreements were made) to an unknown number of appointments.

Monitoring the school after the inspection visit Recollection Acceptance New policy Change of policy ' 0 ' means that none of the schools was monitored after the school visit (there proved to be no variance in these scores).

This percentage is based on the questionnaire which was administered six months after the inspection visit. In the questionnaire the improvement suggestions and poor aspects of the school which had been communicated with the school during the visit, or in the inspection report were presented to the school. The school leader then was asked to fill out, for each school, weakness and/or improvement suggestion, whether they recollected it, agreed with the evaluation that it was weak, and whether it had led to adaptation of current school policy, or to completely new school policy. Percentages can vary from $0 \%$ (the school does not remember/agree with, use any of the remarks on poor performance, and/or suggestions for policy development) to $100 \%$ (the school remembers/agrees with and uses all the feedback).

Cumulated effect The percentage is the sum of the percentages for new and adapted school policy. The sum percentage shows which part of the feedback has led to school improvement activities. Percentages can vary between $0 \%$ (the school has not used any of the feedback for policy making) to $100 \%$ (the school has used all the feedback). 
TABLE 4: Scores for school features and school inspection characteristics

\begin{tabular}{|c|c|c|c|c|c|c|}
\hline Case Number & Innovation Capacity & School Environment & Unsatisfactory Scores & Feedback & Agreements & Monitoring \\
\hline 1 & 2.52 & $19 \%$ & 7 & 42 & 0 & 0 \\
\hline 2 & 2.17 & $28 \%$ & 14 & 39 & 0 & 0 \\
\hline 3 & 3.32 & $7 \%$ & 3 & 29 & 0 & 0 \\
\hline 4 & 3.69 & $15 \%$ & 6 & 27 & 0 & 0 \\
\hline 5 & 3.37 & $52 \%$ & 11 & 49 & 0 & 0 \\
\hline 6 & 3.46 & $9 \%$ & 7 & 43 & 0 & 0 \\
\hline 7 & 2.34 & $11 \%$ & 10 & 36 & 3 & 0 \\
\hline 8 & 3.02 & $27 \%$ & 4 & 45 & 0 & 0 \\
\hline 9 & 3.45 & $4 \%$ & 1 & 24 & 0 & 0 \\
\hline 10 & 3.56 & $11 \%$ & 3 & 35 & 0 & 0 \\
\hline
\end{tabular}

Note: As a result of the poor registration of the number of unsatisfactory scores and the number of improvement suggestions, the results of Case 4 are not fully reliable for this variable. 
TABLE 5: Responses from the schools (as a percentage)

\begin{tabular}{lccccc}
\hline $\begin{array}{l}\text { Case } \\
\text { Number }\end{array}$ & Recollection & Acceptance & $\begin{array}{c}\text { New } \\
\text { Policy }\end{array}$ & $\begin{array}{c}\text { Policy } \\
\text { Change }\end{array}$ & $\begin{array}{c}\text { Cumulated } \\
\text { Effect }\end{array}$ \\
\hline 1 & 89 & 64 & 12 & 24 & 36 \\
2 & 54 & 57 & 36 & 18 & 54 \\
3 & 75 & 65 & 31 & 10 & 41 \\
4 & 100 & 67 & 33 & 33 & 66 \\
5 & 79 & 62 & 45 & 18 & 63 \\
6 & 74 & 44 & 26 & 14 & 40 \\
7 & 59 & 44 & 17 & 17 & 34 \\
8 & 75 & 53 & 36 & 9 & 45 \\
9 & 86 & 63 & 8 & 4 & 12 \\
10 & 76 & 49 & 0 & 17 & 17 \\
\hline
\end{tabular}

amount of feedback, the number of improvement suggestions, the number of written agreements on school improvement initiatives, the intensity of the school improvement monitoring after the visit, and the number of school improvement activities following the inspection visit.

Firstly those schools which received a high number of unsatisfactory inspection scores (the schools in cases 2, 5 and 7) were compared to the cases which received few unsatisfactory inspection scores (cases 3, 8, 9 and 10). The comparison showed that the schools with the highest number of unsatisfactory scores did not initiate more improvement processes than the schools which were assessed more positively. For example, in case 7 the school initiated a higher number of improvement activities than the schools in cases 3 and 8 , and the number of improvement initiatives in cases 3 and 8 did not differ substantially from the number of improvement initiatives in cases 2 and 5 . Thus, in these cases the number of unsatisfactory scores did not seem to influence the number of school improvement activities. Next, the amount of feedback and the number of improvement suggestions in cases $1,5,6$, and 8 (where a high level of feedback and many improvement suggestions were given) were compared to cases 3, 4 and 9 (in which less feedback and fewer improvement suggestions were given). The number of school improvement activities did not differ substantially between these cases - in other words, the quantity of feedback and the number of improvement suggestions did not explain why some schools initiated a higher number of improvement processes than others.

Only one inspector (the inspector in case 7) made written appointments with a school to address the school improvement 
initiatives to be undertaken, and none of them conducted follow-up monitoring after the school inspection. Therefore, no cases could be compared on the basis of the features of school inspections. In case 7 , however, the school staff felt that it had no choice with regard to the initiation of improvement activities, once appointments had been made with the inspector (although the Inspectorate does not have any formal means of sanctioning schools). If this attitude is pervasive it could indicate that appointments to address school improvement activities do promote school improvement following inspection visits.

Combinations of inspection features seem to explain differences in the responses from schools to school inspections more than do characteristics of school inspections separately. Further analyses found that the manner in which inspectors communicate feedback to schools, and the consequences they attach to the feedback, do play a role. Feedback presented only as something the school should attend to, but not combined with any further appointments, contributes only to a small extent to school improvement initiatives. Feedback about school aspects assessed as unsatisfactory and combined with written agreements, seem to provide the strongest impulse for school improvement. Such an impulse is, however, not necessary for schools which had previously intended to improve the aspects on which they underperformed; but in these cases the feedback is not without value, as these schools may use the feedback from the school inspector to press school staff to change the way in which they work (cases 2 and 7). In case 1 the school leader incorporated the feedback from the school inspector into the school's quality assurance cycle.

\section{Features of Schools}

It was expected that schools' innovation capacities and the support from the school environment would contribute to school improvement initiatives after inspection visits. The innovation capacity of the schools in cases 4, 6, 9 and 10 proved to be higher than that of the schools in cases 1, 2 and 7. However, two of the four schools with high innovation capacity (cases 9 and 10) initiated only a few improvement activities. The schools with low innovation capacity initiated a relatively high number of improvement initiatives. This led us to conclude that contrary to expectation the level of innovation capacity did not influence the number of improvement activities initiated after an inspection visit.

Next, the role of the school environment was analysed. Cases 2, 5 and 8 , in which it was found that the school environment provided 
a high level of support, were compared to cases 3,6 and 9, in which there was little support from the environment. The number of improvement initiatives was not found to differ significantly between these two groups of schools. Therefore the support from the school environment did not explain differences between schools in the number of improvement initiatives instigated after inspection visits.

\section{School Response}

It was hypothesised that the recollection of the feedback provided to schools would influence the extent to which the feedback was accepted, and that the degree to which feedback was accepted by schools would influence the number of improvement processes initiated by the school.

Those schools with the greatest recollection of the feedback (schools in cases 1,4 and 9) were compared to the schools which remembered least (cases 2 and 3). Results indicated that recollection and acceptance of feedback do not appear to be significantly related to the number of school improvement initiatives: the school in case 3 had greater acceptance of feedback than the schools in cases 1 and 9 and the two groups of schools did not differ much on the acceptance of feedback.

The schools in cases 1, 3 and 4 (those which had the highest scores on the acceptance of feedback measure) were compared to the schools in cases 6,7 and 10 (schools which had the lowest scores on the acceptance of feedback measure). Results indicate that feedback acceptance and improvement processes do not seem to be significantly related as only the school in case 10 used substantially more feedback for improvement activities than the other schools. Moreover, the two groups of schools do not differ substantially in the number of improvement processes they initiated.

\section{Conclusions}

The conclusions about the impact of school inspections and about the influence of specific features of schools and of school inspections on school improvement are summarised below.

\section{Effects}

- All schools were found to use the feedback received from the school inspectors to improve their functioning, and after six months all schools were still carrying out improvement plans. 
- Those improvement initiatives which had been completed were relatively easy to implement suggestions made by the school inspector, such as implementing or abolishing student tests, or expanding the amount of time spent on language education.

- The number of improvement initiatives did not seem to be associated with the amount of feedback the school accepted, and the amount of feedback concurred with by the schools was also not found to be associated with the amount of feedback the school principal remembered six months after the school visit.

\section{Features of Schools}

- The comparison of cases of schools with a high innovation capacity and high levels of support from their environment to cases with relatively low innovation capacity and low environmental support found that neither variable explains differences in the number of improvement initiatives undertaken after school inspection visits.

\section{Features of School Inspections}

- The results of the case studies showed that the following aspects of school inspections taken separately do not explain differences in the number of improvement activities initiated by schools: the number of unsatisfactory scores; the amount of feedback; the number of improvement suggestions; and the number of appointments made.

- Inspectors giving feedback about poor performance aspects of a school - and simultaneously making appointments with the school to improve these aspects - do, however, seem to make a difference to school improvement. School inspectors should therefore combine these modes of operation when trying to promote school improvement.

- Another important finding is that the amount of feedback provided does not contribute significantly to school improvement, but the way it is given does: in a directive sense, together with unsatisfactory assessments in the school report, and agreements about improvement of the weak aspects of functioning within a certain period.

This article started with an analysis of the inconsistent findings on the relationship between school inspection and school improvement. In the research presented here this relationship has been studied further by analyses of how inspections can lead to better functioning 
schools, and by exploring those relationships which proved to be researchable within the context of the study.

Some of the expected relationships were not confirmed in the cases studied and those results shed new light on the topic of interest. An important general conclusion can be drawn: that the assumption that the inspection of schools alone will automatically improve schools is naïve, and that contingencies are very significant: e.g. the type of school being inspected, how the inspector deals with the school, how compelling the feedback received by schools is, how specific the improvement appointments about schools and inspectors are.

The results also indicate that interactions between characteristics instead of simple one-to-one relationships are more promising in terms of finding explanations for differences between schools regarding the extent of improvement as a direct result of inspections.

The cases studied showed that school improvement is usually a very difficult activity for the average school. The improvements accomplished in the schools proved to be those which were simple, straightforward changes. More complex changes ask much of schools and of inspectors. Inspecting schools without follow-up and monitoring activities is probably not very effective. The challenge is to discover more precisely which prerequisites make the probability of school improvement greater.

The trend is to grant schools and their environments a more important role in guaranteeing school quality. As this study showed that external school inspection does encourage school improvement under specific conditions, care should be taken in limiting the role of external school inspectors. However, even more care should be taken given the possible risks of internal inspection boards (Janssens, 2005). These risks include, for example, that internal boards lack the required expertise on educational quality and school improvement, that internal boards may be incapable of independently assessing school quality, and that internal boards may take an advisory role instead of controlling quality.

\section{REFERENCES}

BRIMBLECOMBE, N., SHAW, M. and ORMSTON, M. (1996) Teachers' intention to change practice as a result of OFSTED school inspections, Educational Management and Administration, 24 (4), 339-354.

CHAPMAN, C. (2001) Changing classrooms through inspection, School Leadership and Management, 21 (1), 59-73.

CULLINGFORD, C. (Eds) (1999) An Inspector Calls: Ofsted and its Effect on School Standards (London, Kogan Page). 
DRONKERS, J. and VEENSTRA, R. (2001) Schoolprestatie-indicatoren in het voortgezet onderwijs: start, reacties en vervolg. In A.B. DIJKSTRA, S. KARSTEN, R. VEENSTRA and A.J. VISSCHER (Eds) Het oog der natie: scholen op rapport; standaarden voor de publicatie van schoolprestaties (Assen, Koninklijke Van Gorcum BV), 21-36.

EARLEY, P. (1998) School Improvement after Inspection; School and LEA Responses (London, Sage).

EDUCATIONAL COUNCIL (2001) De markt meester? Een verkenning naar marktwerking in het onderwijs. [Ruled by the market? An exploration of marketisation in education] (Den Haag, Onderwijsraad).

EHREN, M.C.M. and VISSCHER, A.J. (in press) Towards a theory on the impact of school inspections, British Journal of Educational Studies.

EHREN, M.C.M. and DE WOLF, I. (in press) Attitudes and behaviour of school inspectors; are there any systematic differences between types of inspectors?

EHREN, M.C.M., LEEUW, F.L. and SCHEERENS, J. (2005) On the impact of the Dutch Educational Supervision Act: analyzing assumptions concerning the inspection of primary education, American Journal of Evaluation, 26 (1), 60-76.

FERGUSON, N., EARLEY, P., FIDLER, B. and OUSTON, J. (2000) Improving Schools and Inspection: The Self-Inspecting School (London, Chapman/Sage).

FIDLER, B., EARLEY, P., OUSTON, J. and DAVIES, J. (1998) Teacher gradings and OFSTED inspections: help or hindrance as a management tool? School Leadership and Management, 18 (2), 257-270.

FULLAN, M.G. (1991) The New Meaning of Educational Change (London, Cassell Educational).

GEIJSEL, F. (2001) Schools and Innovations; Conditions Fostering the Implementation of Educational Innovations (Nijmegen, University Press).

GEIJSEL, F. (2003) Ondersteuning van omgaan met verschillen tussen leerlingen in het basisonderwijs met behulp van een innovatie volgsysteem [Supporting the handling of differences between primary school students by means of an innovation monitoring system] Interne notitie ESO/KUN.

GEIJSEL, F., BERG, VAN DEN R. and SLEEGERS, P. (1996) Het innovatief vermogen van scholen in het basisonderwijs: een tweede vooronderzoek [The innovation capacity of primary schools; a second pilot study], Pedagogische Studiën, 73, 42-55.

GRAY, J. and WILCOX, B. (1995) Good School, Bad School: Evaluating Performance and Encouraging Improvement (Buckingham, Open University Press).

JANSSENS, F.J.G. (2005) Supervision and Governance (Enschede, Universiteit Twente).

KARSTEN, S. and VISSCHER, A.J. (2001) Ervaringen met het openbaar maken van schoolprestaties in Engeland en Frankrijk [Experiences with publishing school performance indicators in England and France]. In A.B. DIJKSTRA, S. KARSTEN, R. VEENSTRA and A.J. VISSCHER (Eds) Het oog der natie: scholen op rapport; standaarden voor de publicatie van schoolprestaties (Assen, Koninklijke Van Gorcum BV), 36-54.

KOGAN, M. and MADEN, M. (1999) An evaluation of evaluators: the OFSTED system of school inspection. In C. CULLINGFORD (Eds) (1999) An Inspector Calls: Ofsted and its Effect on School Standards (London, Kogan Page), 9-32.

LEEUW, F.L. (2002) Reciprocity and educational evaluations by European inspectorates: assumptions and reality checks, Quality in Higher Education, 8 (2), $137-150$.

MATTHEWS, P. and SAMMONS, P. (2004) Improvement through Inspection (London, Ofsted). 
OUSTON, J., FIDLER, B. and EARLEY, P. (1997) What do schools do after OFSTED school inspections - or before? School Leadership and Management, 17(1), 95-104.

REEZIGT, G.J. (2001) A Framework for Effective School Improvement. Final Report of the ESI Project (Groningen, GION, Institute for Educational Research, University of Groningen).

ROSENTHAL, L. (2004) Do school inspections improve school quality? Ofsted inspections and school examination results in the UK, Economics of Education Review, 23 (1), 143-151.

SHAW, I., NEWTON, D.P., AITKIN, M. and DARNELL, R. (2003) Do OFSTED inspections of secondary education make a difference to GCSE results? British Educational Research Journal, 29 (1), 63-76.

STANDAERT, R. (2000) Inspectorates of Education in Europe; a Critical Analysis (Flanders, Ministry of Education).

VISSCHER, A.J. and COE, R. (Eds) (2002) School Improvement through Performance Feedback (Lisse, Swets and Zeitlinger).

WILCOX, B. and GRAY, J. (1996) Inspecting Schools: Holding Schools to Account and Helping Schools to Improve (Buckingham/Philadelphia, University Press).

Correspondence

M.C.M. Ehren

University of Twente

Faculty of Behavioral Sciences

Department of Educational Organization and Management

P.O. Box 217

7500 AE Enschede

The Netherlands

E-mail: mcm_ehren@hotmail.com. 